International

Medical Society

http://imedicalsociety.org

\title{
Work Precariousness In Family Health Strategy
}

Palmyra Sayonara de Goes ${ }^{1}$, Soraya Maria de Medeiros², Yanna Gomes de Sousa ${ }^{3}$, Ana Elisa Pereira Chaves ${ }^{4}$, Aline Dannyele Souza de Oliveira ${ }^{3}$, Danielle Rezende Ferreira ${ }^{3}$, Xênia Alves Freire ${ }^{5}$, Arleusson Ricarte de Oliveira ${ }^{6}$, Marilia Alves ${ }^{7}$, Maria Luísa de Almeida Nunes ${ }^{8}$, Marília Souto de Araújo ${ }^{9}$, Kennya Cristina Mendes Cocentino de Medeiros ${ }^{10}$

\section{Abstract}

Objective: to analyze the ways of precariousness work of the Family Health Strategy (FHS) nurses.

Method: this is a qualitative study, with analysis of categories that emerged from the research through dialogue with the authors studied on the precariousness of health work. The methodology of oral history and semi-structured interviews were used generating questions as information collection instrument.

Results: we performed a study of a group of nurses from the FHS, with a predominance of females, married, aged 29 and 47 years old. Nurses understand the work precariousness of their working conditions, lack of structural and infrastructural conditions in which the working process takes place.

Conclusions: nurses of the FHS analyzes their working conditions with a level of uniqueness of each FHS; some with a greater level of difficulty, showing the lack of materials and supplies and the lack of adequate physical infrastructure for carrying out their work process.

\section{Keywords}

Work; World of the Work; Precariousness; Nurse; Health Strategy.
1 Nurse. Master the Graduate Program in Nursing, Federal University of Rio Grande do Norte/UFRN. Natal (RN), Brazil.

2 Nurse. Ph.D. in Nursing. Professor of the Department of Nursing, Federal University of Rio Grande do Norte/ UFRN. Natal (RN), Brazil.

3 Nurse. Master student of the Graduate Program in Nursing, Federal University of Rio Grande do Norte/UFRN. Natal (RN), Brazil.

4 Nurse. Ph.D. student of the Graduate Program in Nursing, Federal University of Rio Grande do Norte/UFRN. Natal (RN), Brazil

5 Nurse. Master the Graduate Program in Nursing, Federal University of Rio Grande do Norte/UFRN. Natal (RN), Brazil.

6 Nurse. Ph.D. student of the Graduate Program in Nursing, Federal University of Minas Gerais MG, Brazil.

7 Nurse. Ph.D. in Nursing. Professor at the Department of Nursing, Federal University of Minas Gerais MG, Brazil.

8 Nurse. Master. Professor of Nursing Department at the Federal University of Campina Grande - UFCG.

9 Nursing Student by the Federal University of Rio Grande do Norte/ UFRN. Natal (RN), Brazil.

10 Nurse. Formed by Federal University of Pernambuco/UFPE. Recife (PE), Brazil.

\section{Contact information:}

\section{Yanna Gomes de Sousa.}

झyanna_gomes@yahoo.com.br

\section{Introduction}

The Family Health Strategy (FHS) aims to reorganize the practice of health care on a new basis and replace the traditional model, taking 
health closer to the family and, therefore, improving the quality of life [1].

It is highlighted as an innovative strategy and restructuring of actions and health services, breaking the focal vision, unidirectional, technical and biological of the human being.

It is within the context of the Unified Health System (SUS). Thus, we consider important to make some opening remarks on it. SUS has advanced about improving access to services, but little progress about policies on a labor force that produces the effect in practice in its scope.

The workforce is a critical aspect of the construction and consolidation of the Brazilian health system. There are many challenges to be faced and edges to be trimmed to a full, efficient and effective implementation of SUS, especially in the FHS.

These challenges are the poor distribution of the labor force, determined and conditioned by inter and intra-regional inequalities; the based training process even in the teaching model that values education in basic sciences, devaluing aspects of health promotion and prevention; disarticulation between training institutions and services; disassociated the teaching work; the absence of social control in the formulation and implementation of specific policies [2].

In this sense, the dilemmas of this discussion are focused on the links, the comprehensive care and the possibilities and limits of the health of workers. In this context, there is a link that is one of the major conflicts in the sphere of this work process: the lack of guarantee of the employment contract, the discontinuance of activities and services, the increasing responsibilities for professionals and precariousness health work.

A large challenge for SUS is the ways of hiring, the wage, the new and diverse forms of labor bonding and poor working conditions in the current context.

In this context involving labor relationships in the FHS everyday, the nurse has found some problems related to forms of contract, the equipment infras- tructure (heterogeneity of the physical structure of the family health units), the dynamics of assistance (overhead service that generates difficulties in making planning and discuss the dynamics of the work); different styles of management of family health teams, setting relationships sometimes approximate and sometimes conflicting and expectations beyond the family health teams with local authorities. [2]

It is noticed that the work of nurses in the FHS has no a simplistic characteristic or low subjective complexity. There is a scenario full of responsibilities, with built needs and needs that emerge simultaneously.

The FHS reality is not total predictable, although initially it seems to be. The peculiarities and the differences emanating from the groups, homogeneous or heterogeneous in their ways of socially producing and reproducing, there are complex elements, concerning ways of living the life of each and their needs.

Starting from the idea that the precariousness of the working world is a historical and ontological condition of the labor force as merchandise, that is, since the labor force is a merchandise; the living labor carries the stigma of social precariousness [3].

The precariousness of work is the social adversity caused by the manipulation of competition for employment. Inserted in the situation of precariousness, workers lose the ability to face the suffering, domination and alienation to which they are subjected, defending by silence and denial of their and others' pain [4].

Thus, the discussion about the experiences in the scenarios of practice in precarious work in primary health care working relationships and its consequences for life and health of the general population is of great scientific and social relevance.

The interface with the social dimension is the contribution to the nurse's reflection on their practices. This reflection can happen in the category dialogue through the class councils; in councils and SUS health conferences, in Precarious Boards of 
work and workers, through the National Humanization Policy, bringing contributions to the studies and reflections on the current situation.

Studying the precariousness of the nurse's work in the current situation, it is necessary to understand the challenges faced by workers in the Family Health Strategy, which are located in a setting built by current and supported economic legally policy by SUS/ FHS, which is characterized by insecurity, instability, and poor working conditions.

The precariousness in this study will be understood in the structural work sense. Thus, it goes beyond the concept of lack of labor links, also meaning the absence of protective labor legislation, structural conditions, and infrastructure of the areas where the work is done, the overload of activities and responsibilities of staff and the strategies used to perpetuate this context.

In this context, discussing precariousness of the nurse's work in the Family Health Strategy is our object of study. Therefore, the following question was built: What are the working conditions that contribute to the precariousness of the nurses working the FHS?

\section{Method}

This is an analytical study with a qualitative approach considering that it works with the depth of relationships, processes, and phenomena that cannot be reduced to quantification. [5]

In this study, as, the information gathering technique based on oral history was used as a way to approach the object. [6] The target population health strategy for the nurses of the Family of a municipality in northeastern Brazil.

The inclusion criteria for the sampling process were: being a nurse of the municipal FHS. Nurses who have been removed from service for leaving reasons, health or vacation were excluded.

The study population consisted of 10 nurses, remaining seven after applying the inclusion and ex- clusion criteria. The research project was approved by the Research Ethics Committee of the Federal University of Rio Grande do Norte, which approved the survey by Opinion 0222.0.051.000-09.

The completion of data collection and information took place from July to August 2010. Later, the interview was held. The study used research technique of oral history through an interview by recording digital voice recorder model Sony ICD-PX720, in HD mode, with high-definition voice and sound.

The script presented open and closed questions, enabling to understand the theme of the precariousness of the FHS nurses' work. The recordings totaled approximately 02 hours of audio. After transcription, there was the categorization of variables such as age, gender, marital status, the level of education, working arrangements and service time.

After the conference of the interviews, a qualitative analysis of the categories found was started to achieve the objectives of the study. They were the meanings of precarious work for nurses of the FHS and working conditions.

As a procedure for the analysis, nurses were called WORKERS, to understand that the nurse is a health worker, reality transformer, through their practices, their work process. Consequently, they were denominated in W1, W2, W3, W4, W5, W6 and W7.

\section{Results and Discussion}

Of the 07 nurses interviewed, the predominance was the age group between 29 and 34 years old with 05 nurses. In this scenario, the minimum age was 29 years old and the maximum was 47 years old. The mean age of the FHS nurses was 35 years old. Regarding the gender, they were most predominantly female, with 06 of the FHS nurses. This reality does not differ from the data found in the history of nursing. Regarding marital status, all 07 nurses were married. Concerning the education level, all nurses have graduation. Regarding the labor 
regime, all workers claim to have 40 hours with service time average in the FHS ranging from two years to nine years.

\section{The FHS Nurses and the Work Meanings}

When seeking the understanding of work by the FHS nurses, different speeches were found. One of them, understood by the minority (1), highlights the work as simply carrying out of activity, whether conscious or not, regardless of the place and financial purposes. Thus, W4 stated:

Work for me is any activity that is made inside or outside of a household; it is for profit or not.

W4.

In this understanding, the nurse does not articulate work with any other category, considering it as any activity, historically and socially decontextualized. The meaning of work for FHS nurses also sets as an expression of human achievement when the W1 stated:

Work is the drudgery of everyday life. It is my greatest pleasure; I have to dawn the day and do the work. It is our strength; it is something that fulfills me. Are you talking to me? It's something that fulfills me, that when I wake up, I feel like doing and that gives satisfaction.

The expression of their human achievement at work is evident in the speech of the nurses, articulating human labor, satisfaction and pleasure. This brings us to the time of the craft production, when the work reached its maximum degree human-achieving, and in which the employee plans and interferes with all its productive process.

With this human achievement of feeling alive, feeling human is possible thinking of why of all the FHS nurses answer during the interview were satisfied with what they do.

Another meaning of work understood by most of the nurses (05) is the way in which man transform something, acting on his insertion space, interacting as a social and becoming man; understanding anchored in Marx [7] definition (1989), that is, work is the way in which man produces and reproduces socially, the man recognizes himself as a social being; as shown below:

Work... work is an activity that we develop, which may or may not be paid. One thing is employment, in my view, work is another thing. So work is an action that you perform that may or may not be paid, and that is a supplement that makes us, places us as social beings.

Work is, I always make a difference, there are employment and work. In my point of view. The job is something that you do not exercise much. And work is when you do it, it is effective; you perform some action, and this action often backs. It has the reward.

For Marx [7] (1989), it is from the work and by the work that man becomes a man, building and transforming the society. In nursing, the work holds its institutional space, social visibility and, in that case, the dynamic articulation of the health work process, there is the contribution to the transformation of the concrete reality $[8,9]$.

Work is central to the life of the subject as a process of the men and the nature participating; process in which the human being with his action, drives, regulates and controls his material exchange with nature $[10,11]$.

The FHS nurse also shows a difference between labor and employment, expressing the work as a transformer, as an insert element of man in the society, as a category that fosters human dignity. For these nurses, the performance of this work has an impact on society, and it has a reward of his action, his work done. 


\section{The Meaning of Precarious Work for FHS Nurses}

The exercise to look into the precarious work in the SUS space shows various elements that need to be reflected. The understanding of precarious work for the SUS is based on the absence of links and lack of social protection of labor rights. But, it is clear that this conception does not address the objective and subjective realities found in the FHS scenario.

FHS nurses study participants brought understandings that are shared with the concept of precarious work of this study.

I believe that precarious work is one that does not provide you the right conditions for you to perform your activities productively, resolute. If there are structural conditions for me to develop my activities, I will have a decrease in my production, my resolution, my income as a nurse in the family health unit.

Precarious work, I think is the way you are doing it in a way that you will not be satisfied and that the people are not well attended. With the lack of personal resources, lack of physical resources, lack of material resources, all this somehow added such precarious work.

You work on improvisation, you cannot afford and you will often not as I said earlier, you will not, that will not fit then you will improvise.

Precarious work is one that is weak. When you exercise the activities, but you cannot develop them well, because they lack something that is leaving their precarious, fragile work.
Precarious work is what you exercise without conditions, without proper conditions for its implementation, and it ends up compromising the quality of work that you're exercising. The work is not done only with the professional will; there are structural, physical and even human conditions.

The conceptions of the FHS nurses, in its entirety, corroborate and converge on the design of job insecurity from the working conditions, the existence of means and tools, work process design made from the basic elements for its implementation, as Marx7 (1989) says: the work itself, or the guided activity to an end, the work object and the instruments or means of work.

Precarious work has been identified as an obstacle to the development of the public health system. This management compromises the relationship of workers with the system and affects the quality and continuity of essential services provided by SUS [10, $11]$.

\section{When Family Health Strategy Nurses Talk About Precariousness Working conditions}

The question of working conditions aims to cause concern about what is understood about the precariousness of work. When asked about working conditions, nurses are positioned differently. Thus, the precariousness elements were found in the statements of employees, at times explicitly, at other times covertly, as if they show fear or need to justify something to someone.

At that time, it was showed the contradiction between the reaction to the question asked by the researcher, felt and recorded in the field notebook and explicit statements by some employees, whose way of responding reveal embarrassment.

The FHS nurse reported that their working conditions are great, but to clarify them, it enters a process of affirmation and denial, which contradict each other. 
Well, let's start with the physical. The physical structure of the unit where I work was quite nice, despite being old. At the time we went through a renovation, but the secretariat, it soon readily got a good structure, it is not a unit structure, but it includes all professionals, comfortable. Shall we say, comfortable in quotes (makes a gesture with hands), but giving so we can carry out the activities, isn't it? I feel quite comfortable in the office; I have quite proceeded, right? And I am very satisfied with these conditions.

Impressions during the interview refer to the elements that permeate the working relationships: fear of losing their jobs, fear of displeasing superiors, fear of coercion. It does not have the elements and is not intended to reduce the discussion to these impressions, but does not exclude the fear of losing the space in the world of work. Nowadays, "there is a concern of many of the individuals (...) to keep their jobs according to their expectations and prospects [12]."

Another disturbing element in the process is thatimmersed in this context; the worker is often blamed for his poor working conditions as if he has all the coping strategies and resolution of this reality. This liability is satisfied in various ways and through various organs, such as the $\mathrm{MOH}$, in the audits, as stated by W2:

What I have not to satisfy is the physical structure of the health unit where I work. The room that I work has plenty of infiltration, even when the control of the ministry (Ministry of Health) came, she asked if I knew what it was. I said I knew because I was not crazy, and he said that if his roof collapsed it was my fault because I was assisting in those conditions. I said yes, I requested the Secretariat (SMS) to come and do something here, now I cannot go back is 15 children that I have to assist because the secretariat does not come.
The speech of the nurse expresses a dilemma experienced as a worker experiencing, which is the lack of necessary structural conditions - the precariousness versus the reception and humanization problem when the nurse does not perform actions related to that specific group of users. The nurses experience the ethical and professional dilemma of not ignoring the need for the patients, even in nonideal and adequate working conditions, but they are blamed for not having ways and means for carrying out their work process.

In this scenario, the look of the $\mathrm{MOH}$ as the worker's responsibility highlights the problem of not conceiving precariousness from whether or not the conditions for the realization of the FHS nurses' working process. In this context, it is also evident that the professional experience precariousness for many years, he sees it as something natural. The workers begin to relate their working conditions with the worst conditions found or already experienced and not with the right and proper.

My working conditions in strategy I cannot say that they are poor, because if we consider it, if we compare with other colleagues who perform the same functions, we realize that they have a greater precariousness.

W3.

Therefore, the labor precariousness elements are implicit in the words of nurses. Nursing identifies as deprecated in on the recognition aspect of the work and professional development about other FHS categories.

The same thing (lack of physical infrastructure for service) happens to him (doctor), but more it happens more with the nursing because unfortunately, it will prioritize which of the two professionals need room to meet the priority and it is never the nursing professional, unfortunately. 
These statements reflect the practice of workers and the provision of services, prioritization of health-care aspects, constituting a reflection of the implanted health policies in Brazil from the 1960s, and hegemonically lived along the history in the Brazilian health sphere.

Regarding other categories, there is an aggravating element. As additional responsibilities to nurses' working process, there are also other professionals of the FHS. The absence of conditions for the performance of collective work overloads the nurse responsibilities and functions from the daily demand of the FHS.

One of the things that affect the operation itself of the unit and consequently the work of nurses comes from the community dissatisfaction thinking that health care is never enough. This contributes to that in a way; the nurse sometimes absorbs a part of this activity, a solicitation of tests that should be done by the doctor and we ended up doing because the customer does not have access to a doctor. So, that sometimes hinders some of our activities.

(...) And another precariousness is that the FHS is not further understood by the people and not by peers, then the nurse just overwhelmed in the Family Health team because often will compete and consolidate data that he did not produce, data from other colleagues. Some colleagues, especially the doctor, do not want to get involved with educational activities, still have that healing mentality, lack collection for them too, because if they are not charged, they pretend they have no obligation, and I think it makes a nursing precariousness work. If all categories fulfill their function as they should, our work would be less arduous.

W3.
Means and tools to carry out the work by nurses were also aspects glimpsed in constant speeches in this study. For some of them, there is no shortage of raw materials or materials, being a positive aspect in achieving the nursing work process.

The precariousness of the physical structure of the unit shakes me a lot, because of the equipment, in the same material, so to work, I do not have to complain. Just this.

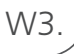

At the moment, I'm seeing that we are having a better quality, whether in material or in working condition.

For other nurses, the means and instruments for the performance of their work process, the lack of materials and supplies are elements that make precarious their work in the FHS. The following workers say:

And besides that, there is, I believe, I think the basic units of municipal health are poorly supplied from the material point of view. So, we do not often have enough serum, gauze, we do not have an oxygen connection to suddenly, at the time of an emergency, I consider this a precarious.

W2.

The precariousness here at work are structural for example the issue of vaccines; the department does not send all vaccines for the center. People have difficult access to the health center and the locations we assist.

In this context of precarious working conditions for performing certain actions and procedures recommended by the $\mathrm{MOH}$, the lack of transportation was one aspect predominant in the speech of the FHS nurses. 
We do not have a secretariat transport to make our home visits. Sometimes we have a very large area, and the patient needs a visit, and we have not supportedby the health secretariat to visit them. Or we go on foot, which is often not feasible, by the distance, the heat, the conditions to the patient who does not have to wait in conditions. So, I think this precarious issue of transportation.

W3.

Here we only have one difficulty, that is transportation. It's the only thing I complain, the lack of a car provided by the health department. In the countryside, we cannot carry out visits because the Health Unit is far away, elderly, puerperal visit, all we need to do.

W5.

There is a lack of transportation, whether for the active search for patients, whether to conduct home visits, both actions required in all health programs of the FHS, prevailed as very important in the speech of nurses.

In the routine of primary care professionals, it is common to find problems related to forms of contract, the equipment infrastructure (heterogeneity of the physical structure of the family health units), the dynamics of care (care burden that creates difficulties in doing planning and discusses the dynamics of the work); different styles of management of family health teams, setting up relationships sometimes approximate and sometimes conflicting [13]; expectations of family health teams with local authorities; conflicts in the relationship between primary care and population, when they cannot meet the demand, for example.

It is noticed that the work of nurses in the FHS has no simplistic character or low complexity subjective. There is a scenario full of responsibilities, needs built and needs that emerge simultaneously. The reality of the FHS is not total predictability, although it seems to be.
The peculiarities and the differences emanating from the groups are homogeneous or heterogeneous in their ways of producing and reproducing socially, with complex elements, concerning ways of living the life of each and their needs.

The nurses have found in this space, the daily need of the work to reflect on their practice; the need to transform it, to promote various forms of impact on people's needs. This scenario marked by contradictions is the diversity and the uniqueness of the problems which fall within the nurse of the Family Health Strategy. A scenario which shows a characteristic accumulation of responsibilities that is increasingly attributed to this professional.

Therefore, it is necessary to understand and bring to the discussion, the precariousness of the family health workers, the spaces practices, unsuitable environment, improper physical structure, the overhead functions, and responsibilities.

\section{Conclusions}

In this study, the FHS nurses relate satisfaction with the work done. This concept of work is brought by the majority, whose design considers the work as a form of human achievement as a way to transform something and be transformed, with the different working job, something relating to feeling useful, a practice that has rewards, the transformative practice of the reality.

Concerning the precarious work, the FHS nurse confirms the design adopted in this study, explaining the lack of structural and infrastructural conditions, the lack of means, instruments and material resources as an enabler for the work precariousness.

The FHS nurses analyze their working conditions with a degree of uniqueness of each FHS; some with a greater degree of difficulty, pointing to the lack of materials and supplies and lack of adequate physical infrastructure for carrying out their work process. In other FHSs, this problem does not exist. 
However, for all the nurses, the difficulty of carrying out some actions is the lack of transportation. Its lack leads to the difficulty of planning and management of the work process of these nurses and the nursing staff, the difficulty in carrying out home visits, some meetings with groups, the active search in general, among other impacts that the lack of this feature causes.

Research on the precariousness of nurses' work highlighted important elements for reflection. The study does not intend to close the discussion on precariousness work in the FHS, searching for contributing to the debate on the theme, which is a reality experienced by the FHS nurses.

\section{References}

1. Ministério da Saúde (BR).Relatório do Seminário Nacional sobre Política de Desprecarização das Relações de Trabalho no SUS. Brasília: Editora do MS, 2003.

2. Junqueira et al. As relações laborais no âmbito da municipalização da gestão em saúde e os dilemas da relação expansão/precarização do trabalho no contexto do SUS. Cad. Saúde Pública. 2010; 26(5):918-928.

3. Alves G. Dimensões da reestruturação produtiva. Londrina: Praxis, 2007.

4. Dejours C. A Banalização da injustiça social. 7.ed. Rio de Janeiro: FGV, 2007

5. Minayo MCS de. O Desafio do Conhecimento: pesquisa qualitativa em saúde. São Paulo: Hucitec-Abrasco, 1998.

6. Meihy JCSB. Manual de História Oral. 4. Ed. São Paulo: Loyola, 2002.

7. Marx K. O capital: crítica da economia política. Rio de Janeiro: Bertrand Brasil, 1989.

8. Almeida MCP,Rocha SMM. O trabalho de enfermagem. São Paulo: Cortez, 1997.

9. Rocha PM et al. Avaliação do Programa Saúde da Família em municípios do Nordeste brasileiro: velhos e novos desafios. Cad. Saúde Pública. 2008; 24(Suppl 1): s69-s78.

10. Góis PS, Medeiros SM,Guimarães J. Neoliberalism and the family health program: about the precarious work. Revista de Enfermagem da Universidade Federal de Pernambuco. 2010; 4 (n. especial):1204-1210.

11. Medeiros SM. As novas formas de organização do trabalho na terceira revolução industrial e a força de trabalho em saúde: estudo em Natal/RN [tese de doutorado] -Escola de Enfermagem de Ribeirão Preto (EERP-USP), 2000.
12. Souza AP. Participação de selênio na resistência à cardiopatia chagásica. Rio deJaneiro. Tese [Doutorado em Biologia Parasitária] - Instituto Oswaldo Cruz;2003.

13. Junqueira et al. As relações laborais no âmbito da municipalização da gestão em saúde e os dilemas da relação expansão/precarização do trabalho no contexto do SUS. Revista Cadernos de Saúde Pública. v. 26, n. 5, 2010. P. 918-928.

14. Minayo-Gomez C, Lacaz FAC. Saúde do trabalhador: novasvelhas questões. Ciênc. saúde coletiva. 2005; 10(4):797-807.

15. Ministério da Saúde (BR). DesprecarizaSUS. Programa Nacional de Desprecarização do Trabalho no SUS. Ministério da Saúde. Brasília: Editora do MS, 2006.

16. Souza MMT, Passos JP, Tavares CMM. Sofrimento e precarização do trabalho em enfermagem. Rev. pesqui. cuid. fundam. (Online). 2015;7(1): 2072-2082.
Publish in International Archives of Medicine

International Archives of Medicine is an open access journal publishing articles encompassing all aspects of medical science and clinical practice. IAM is considered a megajournal with independent sections on all areas of medicine. IAM is a really international journal with authors and board members from all around the world. The journal is widely indexed and classified Q2 in category Medicine. 